\title{
Myocardial and blood T1 quantification in normal volunteers at $3 T$
}

\author{
Christopher T Sibley ${ }^{1}$, Justin Huang ${ }^{1}$, Martin Ugander ${ }^{2}$, Abiola Oki ${ }^{2}$, Jing Han ${ }^{3}$, Marcelo S Nacif ${ }^{1}$, Andreas Greiser ${ }^{4}$, \\ Daniel R Messroghli ${ }^{5}$, Peter Kellman², Andrew E Arai ${ }^{2}$, David A Bluemke', Songtao Liu ${ }^{1 *}$
}

From 2011 SCMR/Euro CMR Joint Scientific Sessions

Nice, France. 3-6 February 2011

\section{Introduction}

T1 mapping is a novel quantitative method for myocardial tissue characterization. Reference values of myocardium and blood have been established at $1.5 \mathrm{~T}$ (Messroghli, MRM, 2007). CMR at $3 \mathrm{~T}$ is a rapidly maturing field, and T1 values generally increase with magnetic field strength, making it necessary to establish new reference values at this higher field strength. The aim of this study is to establish pre- and post-contrast myocardium and blood reference $\mathrm{T} 1$ values at $3 \mathrm{~T}$.

\section{Methods}

Normal volunteers $(\mathrm{n}=9,7$ male, age $39 \pm 12$ years) without cardiovascular disease were scanned at $3 \mathrm{~T}$ (Verio, Siemens) with a 32-channel coil. GRE shimming was used to improve B1 inhomogeneity and transmitter frequency was adjusted according to frequency scout. Modified Look-Locker inversion recovery (MOLLI) images with 2 inversion-recovery blocks were acquired at mid-ventricular short axis view. Eight images were acquired in eleven heart beats with the following parameters: spatial resolution $=1.75 \times 1.75 \times 8 \mathrm{~mm}$ on a $256 \times 180$ matrix, TI initial $=110 \mathrm{~ms}$, TI increment $=$ $80 \mathrm{~ms}$, flip angle $=35^{\circ}, \mathrm{TR} / \mathrm{TE}=2.4 / 1.05 \mathrm{~ms}$. All subjects were administered Magnevist $(0.15 \mathrm{mmol} / \mathrm{kg})$, and multiple post-contrast MOLLI scans were performed at the same pre-contrast position from 3.5-23.5 minutes after contrast injection. T1 maps were generated using MRMap (Messroghli, BMC Med Imaging, 2010). Average blood pool and myocardial T1 values were measured using QMass (Medis), and results were corrected for heart rate.

${ }^{1} \mathrm{NIH}$ Clinical Center, Bethesda, MD, USA

Full list of author information is available at the end of the article

\section{Results}

All Pre- and post-contrast images were interpretable for T1 mapping and contained few artifacts (Figure 1). Mean pre- and post- contrast myocardial and blood T1 value was compiled in Figure 2. Mean pre-contrast myocardial T1 was $1347 \pm 37 \mathrm{~ms}$, and blood T1 was 2076 $\pm 125 \mathrm{~ms}$. Myocardial T1 values at $3 \mathrm{~T}$ were $43 \%$ greater than previously reported at $1.5 \mathrm{~T}$ and consistent with results using different methods (Stanisz, et al, MRM, 2005, Sharma, et al, JMRI, 2006).

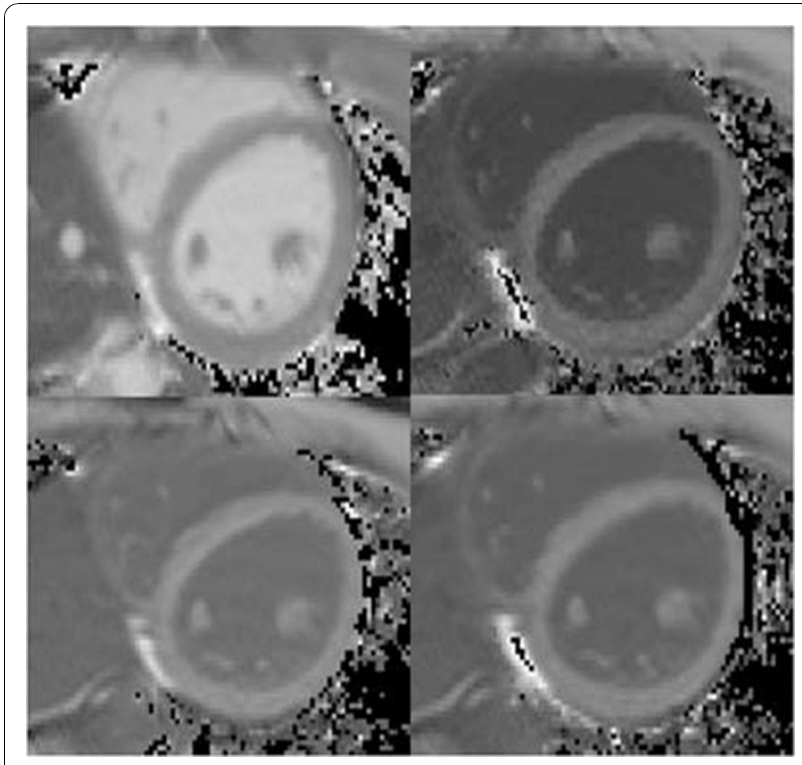

Figure 1 Mid-ventricular short axis T1 maps. Clockwise from top left: pre-contrast, 3.5 minutes post-contrast, 13.5 minutes postcontrast, 23.5 minutes post contrast. 


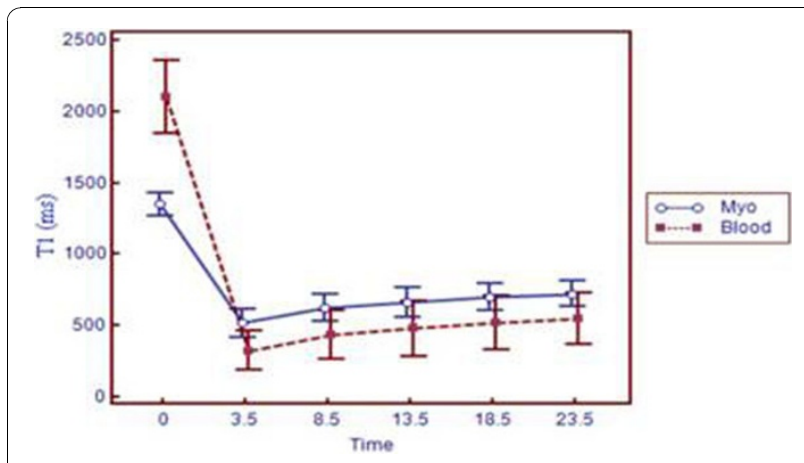

Figure 2 Recovery of absolute myocardial and blood T1 (mean \pm sd) from $0 \mathrm{~min}$ (pre-contrast) to $23.5 \mathrm{~min}$ after $0.15 \mathrm{mmol} / \mathrm{kg}$ of Gd-DTPA.

\section{Conclusions}

High resolution T1 mapping using MOLLI is feasible at $3 \mathrm{~T}$, consistently yielding images of adequate quality for measurement. Pre- and post-contrast normal myocardial and blood $\mathrm{T} 1$ values are markedly higher at $3 \mathrm{~T}$ than at 1.5T. T1 recovery in both myocardium and blood is in near-equilibrium between 3.5 minutes and 23.5 minutes post contrast.

\section{Author details}

${ }^{1} \mathrm{NIH}$ Clinical Center, Bethesda, MD, USA. ${ }^{2} \mathrm{NHLBI}$, Bethesda, MD, USA. ${ }^{3}$ U. S. FDA, Rockville, MD, USA. ${ }^{4}$ Siemens AG, Erlangen, Germany. ${ }^{5}$ Franz-VolhardKlinik Charité, Berlin, Germany.

Published: 2 February 2011
Submit your next manuscript to BioMed Central and take full advantage of:

- Convenient online submission

- Thorough peer review

- No space constraints or color figure charges

- Immediate publication on acceptance

- Inclusion in PubMed, CAS, Scopus and Google Scholar

- Research which is freely available for redistribution

Submit your manuscript at www.biomedcentral.com/submit 